\title{
GLUCOSE INTOLERANCE INDUCED BY OLIGEMIC BRAIN HYPOXIA: THE EFFECT OF TERGURIDE
}

\author{
Věroslav Golda, Jiřina Hilgertová* \\ Institute of Experimental Neurosurgery, University Teaching Hospital, Hradec Králové; \\ (Head: doc. MUDr. J. Náhlovský, CSc.) \\ *Laboratory for Endocrinology and Metabolism,The first Faculty of Medicine, Charles University, Prague; \\ (Head: prof. MUDr. V. Schreiber, DrSc.)
}

Summary: Two series of experiments were performed. In the first one experiments were carried out in Koletsky genetically hypertensive lean female rats and in the normotensive female rats of Wistar strain. Glucose intolerance was induced by oligemic brain hypoxia ( 4 hours of occlusion of both common carotid arteries followed by 44 hours reperfusion). Brain water content were used as a marker of brain edema.Changes in insulinemia and specific insulin binding were used as expression of regulative mechanisms participating in modification of glucose tolerance. The effect of terguride (trans-dihydro-lisuride) was tested.Brain hypoxia induced glucose intolerance in both strains of rat but brain edema was found only in the normotensive females. Both abnormalities were alleviated by terguride treatment. Basal glycaemia was not changed either by the brain hypoxia or by terguride treatment,except normoternsive female where brain hypoxia induced hyperglycaemia. The second series of experiments were carried out in the normotensive females. The arrangement of experiments was the same as in first series except omission of the final glucose tolerance test. Brain hypoxia causes increase in brain water content. The mentioned elevation of brain water content was alleviated by terguride treatmnet. Insulin binding to erythrocytes was not influenced by brain hypoxia. Terguride treatment shows decrease of insulin binding to erythrocytes. Brain hypoxia elevates insulinemia which was not alleviated by terguride treatment.

Key words: Oligemic brain hypoxia; Brain edema; Glucose intolerance; Insulinemia; Insulin binding to erythrocytes; Wistar rats; Koletsky genetically hypertensive rats; Terguride

\section{Introduction}

In our previous paper (2) we documented the abnormalities of glucose tolerance in the obese genetically hypertensive Koletsky (SHR/N-cp) rats as well as in their lean siblings. These genetically based abnormalities of the glucose tolerance were accompanied by alterations of insulin binding to erythrocytes and hepatocytes (8). Insulin binding was decreased in both obese as well as in lean SHR/N$\mathrm{cp}$ rats when compared to the normotensive Wistar rats. On the other hand, the basal plasma insulin was elevated only in the obese animals.

In the other series of experiments (3) the ergopeptine terguride was found to be potent to alleviate the mentioned abnormalities. The study of insulin binding showed that long lasting terguride treatment elevated insulin binding to erthrocytes (4). These finding suggested a possible causal relationship between alleviation of glucose intolerance and the elevation of of insulin binding to erythrocytes.

It must be stressed that the above mentioned results we obtained in the animals where glucose abnormalities are based genetically.
In recent series of experiments we turn our attention to glucose tolerance abnormalities which are induced by brain oligemic hypoxia.

Since the time of Claude Bernard (12) it is known that the hypothalamic lesions cause hyperglycaemia and glycosuria.On the other hand, it was documented $(1,11)$ that hyperglycaemia can be found in brain lesions which do not directly affect the hypothalamus.

The last mentioned data represents the starting point for our experimental arrangement,i.e., we have used not the local brain lesion but we induced brain ischemia invading all the brain.

Glucose tolerance abnormalities induced by oligemic brain hypoxia were submitted to the same ergopeptine, i,e., terguride, which showed beneficial effect in alleviation in glucose tolerance abnormalities based genetically (3).

\section{Material and methods}

Animals

Experiments were carried out in normotensive female rats of Wistar strain and in SHR lean females of Koletsky 
type (10). After weaning at the age of 30 days the animals were kept in groups of four and supplied with water and pelleted diet ad libitum.

\section{Occlusion of common carotid arteries}

Occlusion was performed under Nembutal anaesthesia (45 mg/kg i.p.). The animal was fixed in supine posture, skin was incised in the ventrolateral neck region and the common carotid arteries were separated from the surrounding tissue bilaterally. Both carotid arteries were occluded for four hours by Yasargil Standard aneurism clip (Aesculap, Germany). Then reperfusion period(44 h ) was started.

\section{Glucose tolerance test}

After finishing reperfusion period glucose tolerance test was performed. Blood was sampled to heparinized capillaries (from the retrobulbar plexus under light ether anaesthesia) before glucose loading (basal glycaemia), as well as 30,60,120 and $180 \mathrm{~min}$ after glucose loading. Glucose $(3 \mathrm{~g} / \mathrm{kg}$ b.w., in $30 \%$ solution) was applied intragastrically after $14 \mathrm{~h}$ starvation.

\section{Measurement of brain water content}

After finishing the glucose tolerance test (in the first series of experiements) or after finishing of reperfusion period (in the second series of experiments) the animal was decapitated, the brain was cut off at the boundary between the spinal cord and the oblongata and was removed from the skull. The brain was immediately weighted and placed in a hot air drying box. The drying was finished when the weight of dry brain remained 48 hours the same.

\section{Insulin binding to rat erythrocytes}

In second series of experiments where the animals were submitted to the same procedure as described above, except glucose tolerance test which was omitted,plasma was separated from approximately $3 \mathrm{ml}$ of heparinized blood drawn by cardiac puncture under the light ether anaesthesia.

Erythrocytes were obtained by centrifugation in Ficoll gradient, and incubated in the presence of constant amount ${ }^{125} \mathrm{I}$-insulin( $\left.33 \mathrm{pM}\right)$ at $15^{\circ} \mathrm{C} 3$ hours. Results were corrected for nonspecific binding. The details of the method were published previously (8).

\section{Terguride treatment}

The drug was applied in two daily doses (7.00 and 14.00) for four days before operation and for two days after operation.Terguride maleate was administered at a dose 0.1 $\mathrm{mg} / \mathrm{kg}$ i.p.

\section{Statistics}

The data were analyzed by the Student t-test.

\section{Results}

In the first series of experiments (Table 1 and 2)

Table l:

\begin{tabular}{|c|c|c|c|}
\hline Group & $\begin{array}{c}\text { Basal } \\
\text { glycaemia } \\
\text { mmol/1 }\end{array}$ & $\begin{array}{c}\text { Sum of glycaemia } \\
30,60,120,180 \\
\text { min after glucose } \\
\text { loading mmol/1 }\end{array}$ & $\begin{array}{c}\text { Brain water } \\
\text { content } \\
\%\end{array}$ \\
\hline NR Co & $3.80 \pm 0.28(7)$ & $23.71 \pm 1.38(7)$ & $77.00 \pm 0.11(7)$ \\
Occlu & $5.50 \pm 1.38(7)^{\mathrm{d}}$ & $35.15 \pm 4.73(9)^{\mathrm{d}}$ & $77.39 \pm 0.38(10)^{\mathrm{d}}$ \\
Occlu $\pm \operatorname{Ter}$ & $4.51 \pm 0.50(6)$ & $26.46 \pm 2.31(6)^{\mathrm{d}}$ & $77.63 \pm 0.27(6)$ \\
\hline
\end{tabular}

Means + SEM are presented. Abbreviations: NR - normotensive rats of Wistar strain, Co - control animals, Occlu - bilateral occlusion of carotid arteries,Ter - terguride treatment. Number in bracketts $=$ number of animasls per group. Statistical significance: $\mathrm{a}=\mathrm{P}<0.10, \mathrm{~b}=\mathrm{P}<0,05, \mathrm{c}=$ $\mathrm{P}<0,02, \mathrm{~d}=\mathrm{P}<0,01$.

Table 2:

\begin{tabular}{|c|c|c|c|}
\hline Group & $\begin{array}{c}\text { Basal } \\
\text { glycaemia } \\
\text { mmol/1 }\end{array}$ & $\begin{array}{c}\text { Sum of glycaemia } \\
30,60,120,180 \\
\text { min after glucose } \\
\text { loading mmol/1 }\end{array}$ & $\begin{array}{c}\text { Brain water } \\
\text { content } \\
\%\end{array}$ \\
\hline SHR Co & $5.12 \pm 1.1(9)$ & $35.37 \pm 3.19(9)$ & $77.60 \pm 0.33(9)$ \\
Occl & $5.23 \pm 0.83(14)$ & $47.58 \pm 7.32(14)^{\mathrm{d}}$ & $77.66 \pm 0.25(14)$ \\
Occl+Ter & $5.50 \pm 0.61(11)$ & $37.95 \pm 6.22(11)^{\mathrm{d}}$ & $77.69 \pm 0.30(11)$ \\
\hline
\end{tabular}

Means + SEM are presented. Abbreviations: SHR - lean genetically hypertensive rats of Koletsky (10) type.The other abbreviations are the same as in Table 1

\section{Basal glycaemia}

Considering the control animals, the occlusion shows elevation in the normotensive female rats.Occlusion remains without effect in SHR/N-cp lean females Taking into account occluded animals without drug, terguride treatment does not show any effect.

\section{Glucose tolerance}

Taking into account control animals, occlusion shows elevation in both strains.

Considering occluded animals without drug, terguride shows decrease in both strains of occluded animals.

In this place it is worthwhile to note strain dependence of glucose tolerance in the females rats.

SHR/N-cp lean females show significantly increased the sum of glycaemia 30,60,120 and $180 \mathrm{~min}$ after glucose loading (i.e., there is expressed genetically based glucose intolerance) in comparison with normotensive females (normotensive: $\mathrm{x}=23.71+1.38(7)$ versus hypertensive: $\mathrm{x}=35.37+3.19(10) \mathrm{P}<0,01$.

\section{Brain water content}

Considering the control animals, the occlusion shows elevation only in normotensive females. 
In the second series of experiments (Table 3)

Table 3:

\begin{tabular}{|r|c|c|c|c|c|}
\hline Group & $\mathrm{n}$ & $\begin{array}{c}\text { Basal } \\
\text { glycaemia } \\
\text { mmol/1 }\end{array}$ & $\begin{array}{c}\text { \% of insulin } \\
\text { binding to } \\
\text { erythrocytes }\end{array}$ & $\begin{array}{c}\text { Brain water } \\
\text { content } \\
\%\end{array}$ & $\begin{array}{c}\text { Insulin } \\
\text { pmol/1 }\end{array}$ \\
\hline NR-F Co & 8 & $4.68 \pm 0.88$ & $6.43 \pm 1.34$ & $77.72 \pm 0.15$ & $92 \pm 18$ \\
Occl & 7 & $5.01 \pm 1.16$ & $7.20 \pm 1.30$ & $78.14 \pm 0.28^{\mathrm{c}}$ & $166 \pm 80^{\mathrm{b}}$ \\
Occl+Ter & 9 & $4.51 \pm 0.55$ & $5.23 \pm 2.23^{\mathrm{b}}$ & $77.50 \pm 0.18^{\mathrm{d}}$ & $175 \pm 111$ \\
\hline
\end{tabular}

Means + SEM are presented. Abbreviations are the same as in Table 1.

\section{Basal glycaemia}

Considering the control animals, occlusion shows no effect. mals.

Terguride treatment shows no effect in the occluded ani-

When compared the control normotensive females in the first series of experiments with those in the second series, then in the second series the females show elevated basal glycaemia.

\section{Insulin binding}

Occlusion shows no effect.Terguride treatment shows decrease in occluded animals.

\section{Brain water content}

The occlusion induced elevation. Terguride treatment in occluded animals shows decrease.

\section{Insulinemia}

Occlusion shows elevation of plasma insulin. Terguride in the occluded animals remained without effect.

\section{Discussion}

In our previous papers (3) we documented that terguride treatment shows alleviation of glucose intolerance based genetically in SHR/N-cp obese rats of Koletsky (10) type and in their lean siblings. The mentioned drug induced alleviation of glucose intolerance was accompanied by decrease of insulinemia (4) and by increase of insulin binding to erythrocytes (4). These data suggested a possible participation of insulinemia and insulin binding to tissue in the regulative mechanism of glucose tolerance.

On the other hand, in our previous paper (5) when the effect of dehydroepiandrosterone(DHEA) on the glucose tolerance was monitored, we found in SHR/N-cp lean males that decrease of sum of glycaemia $30,60,120$ and 180 min after glucose loading is accompanied by decrease of insulinemia but insulin binding to erythrocytes was not influenced by DHEA.

In our recent series of experiments similar results were obtained. Very profound glucose intolerance induced by oligemic brain hypoxia was not accompanied by any chnges in insulin binding to erythrocytes (see Table 3 ) and the terguride treatment which alleviated the mentioned glucose intolerance (see Table 1,2) is accompanied, paradoxically, by decrease of insulin binding to erythrocytes(see Table 3 ). When we consider the changes in insulinemia and in insulin binding to tissues as the participants in regulative mechanism of glucose tolerance then our previous (5) as well as our recent data suggest that in glucose tolerance can take part more than one regulative mechanism.

It is valuable to admit one notion to the terguride effect on glucose tolerance in the SHR/N-cp lean females. In table 2 we documented that the last mentioned animals show glucose intolerance which is based genetically. Genetically based glucose intolerance is alleviated by terguride (3).

Oligemic brain hypoxia induces in these animals the superponated glucose intolerance. In table 2 we documented that terguride alleviates this superponated glucose intolerance but the genetically based glucose intolerance was not influenced by terguride. At recent time we are not able to solve this very difficult problem.

The effect of brain hypoxia on the brain water content and the following effect terguride represent the other open question. On one side, when water content was studied in the occluded animals which were submitted to glucose tolerance procedure (i.e., the animals were repeatedly anaesthetized with ether)terguride shows no effect on brain water neither in normotensive females where brain hypoxia indiced elevation of brain water content, nor in the genetically hypertensive females where brain hypoxia showed no effect in brain water content.

On the other hand, when brain water content was studied in the occluded animals which were not finally submitted to the glucose tolerance procedure (i.e., the animals were anaesthetized with ether only once when the blood was sampled by cardiac puncture - see the second group) terguride treatment shows profound alleviationg effect on water brain content in the occluded animals (see Table 3). Goodman and Gilman (7) documented that barbiturates show antiedematose effect.

On the other hand, ether increases intracranial pressure when the edema is induced by intracranial pathologic process(9).We documented that ether maximally elevates the brain water content after $4 \mathrm{~h}$ occlusion of both common carotid arteries (6).On the other hand, ether decreases brain water content immediately after frequently repeated anaesthesia.Moreover, ether elevates brain water content after two days after repeated anaesthesia(6).

Taking in mind the last mentioned data, it cannot be a priori excluded that the different effect of terguride treatment in the occluded normotensive females in the first and the second series of experiments is done by the different regime of ether anaesthesia.Before definite conclusion this question must be submitted to special series of experiments.

Before termination of discussion it cannot be omitted the most difficult question, i.e., what represents the sub- 
stantial differences in the regulative mechanism of glucose tolerance when the terguride induced changes are accompanied by elevation of insulin binding and decrease of insulinemia (see SHR/N-cp lean males - 4) and when the same changes in glucose tolerance but induced by DHEA (5)are not accompanied by any changes in insulin binding and/or insulinemia. Moreover, which regulative mechanism are taking part in the induction of profound glucose intolerance induced by oligemic brain hypoxia, where no changes in insulin binding and elevated insulinemia was found and where the alleviation of this type of glucose intolerance by terguride treatment is nay even accompanied by a descrease of insulin binding to erythrocytes (the recent paper).

\section{Acknowledgement}

This paper was supported by Internal Grant Agency of Ministry of Health of the Czech Republic No 3684-3. The authors wish to thank G.W.Ashe, Imperieal Chemical Industry, Ltd., Pharmacological Division, Macclesfield, U.K., for providing normotensive rats of Wistar strain and Carl T. Hansen, Animal Genetics Division, National Institute of Health, Bethesda, USA, for providing the genetically hypertensive rats of Koletsky type.

\section{References}

1. Cazzano G, Zorzon M, Mase G, Iona LG. Hyperglycaemia at ischemic stroke onset as prognostic factor. Ital J Neurol Sci 1991;12:283-8.

2. Golda V, Petr R. A genetically based animal model of Cushing's disease:glucose tolerance. Physiol Bohemoslov 1988;36:366.

3. Golda V, Cvak L. Terguride but not bromocriptine alleviated glucose tolerance abnormalities and hyperlipidemia in obese and lean genetically hypertensive Koletsky rats. Physiol Res 1994;43:299-305.
4. Golda V, Hilgertová J. Effect of trans-dihydro-lisuride on insulin binding, insulinemia, glucose tolerance and hyperlipemia in SHR Koletsky rats. Physiol Res 1997 (in press).

5. Golda V, Hilgertová J. Effect of dehydroepiandrosterone on lipemia, glucose tolerance, insulinemia, insulin binding to erythrocytes in SHR/N-cp lean rats of Koletsky type. Acta Med (Hradec Králové) 1997;40:31-5.

6. Golda V. Brain water content: effect of anaesthesia. Lek Zpr LF UK v Hradci Králové 1996:41:55 (in Czech).

7. Goodman A, Gilman B. The pharmacological basis of therapeutics. Oxfod:Pergamon Press 1992:364.

8. Hilgertová J, Kummel L, Hovorka R, Golda V. Decreased insulin binding and internalization in hepatocytes and erythrocytes of SHR Koletsky rats depend on the presence of „f" gene and on sex. Metabolic characteristics of hepatocytes from obese rats. In: Insulin and the Cell Membrane. Klimeš I, Howard BV, Kahn RC(edds), Harwood Academic Publishers, London, 1989:81-92.

9. Katzung BG. Basic and clinical pharmacology. San Matheo, California:Appleton and Lang 1989:310.

10. Koletsky S. Pathologic findings and laboratory data in a new strain od obese hypertensive rats. Am J Pathol 1975;80:129-40.

11. Pentelenyi T. Significance of endocrine studies in the general assessment and prediction of fatal outcome in head injury. Acta Neurochir Suppl Wien 1992;55:21-4.

12. Schreiber V. Hypothalamic-pituitary system. St Zdr Nakl 1959:150 (in Czech).

Submitted May 1997.

Accepted June 1997.

Doc. MUDr.,PhDr. Věroslav Golda, CSc., Institute of Experimental Neurosurgery, University Teaching Hospital, 50005 Hradec Králové, Czech Republic. 